\title{
Stratigraphy and structure of the Horton Group, Lochaber-Mulgrave area, northern mainland Nova Scotia
}

\author{
Paul J. TÉnière ${ }^{1}$, Sandra M. Barr ${ }^{2^{*}}$, ANd Chris E. White 3
}

1. Integrated Ocean Drilling Program, 1000 Discovery Drive, College Station, TX 77845, U.S.A.

2. Department of Geology, Acadia University, Wolfville, NS B4P 2R6, Canada <sandra.barr@acadiau.ca> 3. Nova Scotia Department of Natural Resources, P.O. Box 698, Halifax, NS B3N 2T9, Canada

* Corresponding author

Date received:September 2, 2004 Date accepted:January 31, 2005

\begin{abstract}
The Lochaber-Mulgrave area of northern mainland Nova Scotia is underlain by rocks of the Late Devonian - Early Carboniferous Horton Group, in faulted contact with older Devonian and Silurian rocks to the south and west, and younger Carboniferous rocks to the north and east. The Horton Group is divided into (from oldest to youngest) the Clam Harbour River, Tracadie Road, Caledonia Mills, and Steep Creek formations, with a total thickness of at least $4000 \mathrm{~m}$. These units were deposited in a variety of braided fluvial and shallow to deep lacustrine environments, and show lithological and stratigraphic similarities to the Horton Group elsewhere in Nova Scotia. Sparse palaeontological data from macrofossils and spores indicate an age range from Famennian to late Tournaisian. Compared to elsewhere in Nova Scotia, the Horton Group in the Lochaber-Mulgrave area is more deformed and metamorphosed, especially in the southern part of the area near the Roman Valley Fault. The time of regional deformation and metamorphism is constrained to ca. $340-335 \mathrm{Ma}$ by whole-rock ${ }^{40} \mathrm{Ar} /{ }^{39} \mathrm{Ar}$ dating of slate in the Clam Harbour River and Tracadie Road formations. Regional deformation and metamorphism may have resulted from burial by older rocks of the Guysborough block, thrust over the Horton Group in the Lochaber-Mulgrave area from the south as a result of transpression at a restraining bend along the Chedabucto-Roman Valley fault system during juxtaposition of the Avalon and Meguma terranes.
\end{abstract}

\section{RÉSUMÉ}

Le secteur de Lochaber-Mulgrave dans le nord de l'intérieur de la Nouvelle-Écosse repose sur des roches du groupe du Dévonien tardif au Carbonifère précoce de Horton, en contact faillé avec des roches du Dévonien et du Silurien au sud et à l'ouest, et avec des roches carbonifères au nord et à l'est. Le groupe de Horton se subdivise en (de la plus ancienne à la plus récente) formations de Clam Harbour River, de Tracadie Road, de Caledonia Mills et de Steep Creek, d'une épaisseur totale d'au moins 4000 mètres. Ces unités se sont déposées au sein de divers environnements lacustres allant de peu profonds à profonds et d'environnements fluviaux anastomosés; elles présentent des similarités lithologiques et stratigraphiques avec le groupe de Horton ailleurs en Nouvelle-Écosse. Des données paléontologiques éparses tirées de macrofossiles et de spores révèlent une fourchette d'âges du Famennien au Tournaisien tardif. Comparativement aux autres régions de la Nouvelle-Écosse, le groupe de Horton dans le secteur de Lochaber-Mulgrave est plus déformé et métamorphisé, en particulier dans la partie méridionale du secteur, près de la faille de la vallée Roman. Le moment de la déformation et du métamorphisme régionaux se trouve restreint à environ 340-335 Ma par la datation ${ }^{40} \mathrm{Ar} /$ ${ }^{39} \mathrm{Ar}$ de roche totale de l'ardoise dans les formations de Clam Harbour River et de Tracadie Road. La déformation et le métamorphisme régionaux pourraient avoir découlé de l'enfouissement de roches plus anciennes du bloc de Guysborough, qui chevauche le groupe de Horton dans le secteur de Lochaber-Mulgrave à partir du sud, par suite d'une transpression dans une inflexion de retenue le long du système de failles de Chedabucto-vallée Roman pendant la juxtaposition des terranes d'Avalon et de Meguma

[Traduit par la rédaction.] 


\section{INTRODUCTION}

A fault-bounded sequence of clastic sedimentary rocks underlies the Lochaber-Mulgrave area of northern mainland Nova Scotia (Fig. 1). Although generally assumed to be of Devonian-Carboniferous age based on sparse paleontological evidence, the stratigraphic relationship of these rocks to Devonian - Carboniferous units elsewhere in Nova Scotia was uncertain (Schiller 1961; Keppie 1979; Smith 1980, 1981). White and Barr $(1998,1999)$ specifically assigned the rocks to the Horton Group and established a preliminary stratigraphy based in part on earlier work by Smith $(1980,1981)$ and on lithologic similarities to the Horton Group in western Cape
Breton Island (Giles et al. 1997a, b, c; Hamblin and Rust 1989). They recognized that, in comparison to the Horton Group elsewhere in Nova Scotia, rocks in the Lochaber-Mulgrave area are generally more deformed and metamorphosed.

This paper presents evidence for a formal sequence of stratigraphic units in the Lochaber-Mulgrave area and their correlation with formations of the Horton Group in the type area around the Minas Basin, in the St. Marys Basin, and in western Cape Breton Island. It also documents the complex deformation and metamorphism that affected the Horton Group in the Lochaber-Mulgrave area. This paper follows on the earlier description of the units and their depositional environments by Ténière et al. (2002).

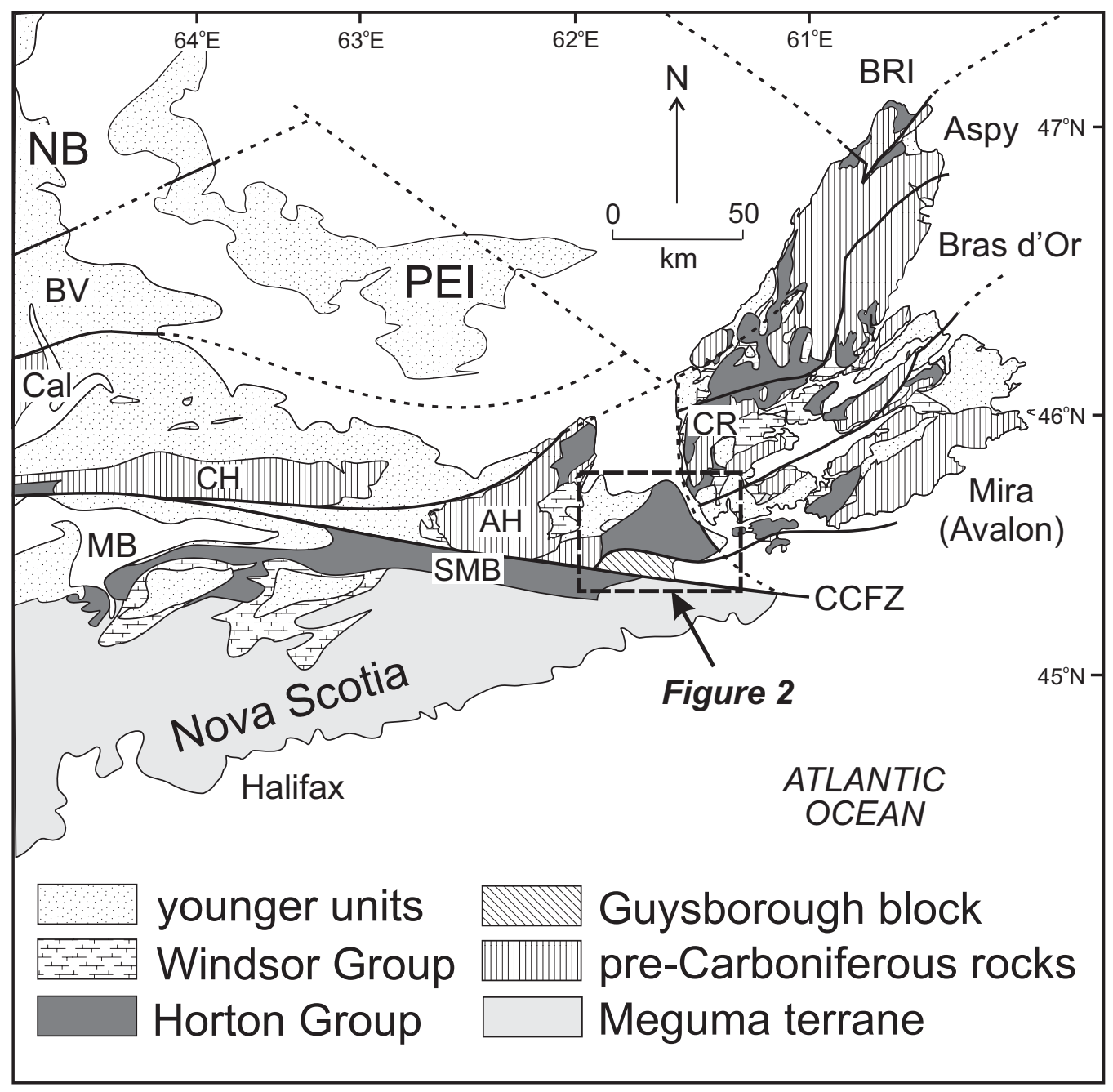

Fig. 1 Simplified geological map of part of the Maritime Provinces showing the distribution of the Horton Group and pre-Carboniferous geological terranes (after Keppie 2000 and Barr et al. 1998). The location of the Lochaber-Mulgrave area is indicated by the dashed box. Abbreviations: AH, Antigonish Highlands; BRI, Blair River inlier; BV, Brookville terrane; Cal, Caledonia terrane; CCFZ, Cobequid-Chedabucto fault zone; CH, Cobequid Highlands; CR, Creignish Hills; MB, Minas Basin; PEI, Prince Edward Island; NB, New Brunswick; SMB, St. Marys Basin. The Guysborough block consists mainly of the Devonian Guysborough Group (Cormier et al. 1995). 


\section{GEOLOGICAL SETTING}

Rocks in the Lochaber-Mulgrave area assigned here to the Horton Group (Fig. 2) are in faulted contact with volcanicsedimentary units of the Late Devonian Guysborough Group to the south (Cormier et al. 1995; White and Barr 1999), the Silurian - Early Devonian Arisaig Group to the west (Murphy et al. 1991), and younger Carboniferous rocks on the north and east. Locally, along the northwestern margin, the sequence is disconformably overlain by the Macumber Formation of the Visean Windsor Group (Boehner and Giles 1993). Faultbounded areas of Triassic polymictic pebble conglomerate and sandstone occur east and south of Guysborough (Fig. 2).

The east-west trending Roman Valley and associated faults, which mark the southern boundary of the Horton Group in the Lochaber-Mulgrave area, are interpreted to be part of the larger Cobequid-Chedabucto fault zone, which developed along the Avalon and Meguma terrane boundary (Webster 1996; Webster et al. 1998). The Glenroy Fault along the northern margin of the map area (Fig. 2) was interpreted by Boehner and Giles (1993) as near-vertical, with dextral strikeslip movement in excess of $1 \mathrm{~km}$ and with significant normal or reverse dip-slip offset. This fault has also been interpreted as part of the Ainslie Detachment, a regional listric normal fault system (Lynch and Giles 1995), and most recently as a zone of relatively minor intraformational extension in the Windsor Group (Thomas et al. 2002). In the eastern and southeastern parts of the Lochaber-Mulgrave area, the Strait of Canso and other faults separate the Horton Group from younger rocks of the Windsor and Mabou groups (Fig. 2).

\section{STRATIGRAPHY}

\section{Introduction}

The Horton Group in the Lochaber-Mulgrave area is divided here into four formations. Two of these formations (Clam Harbour River and Tracadie Road) were established by Smith $(1980,1981)$ and included in Williams et al. (1985). However, the present study and that of White and Barr (1998, 1999) better defined and described these units, and we also have further subdivided the Clam Harbour River and Tracadie Road formations into informal members, based on lithological differences. A third formation, Caledonia Mills, was introduced by White and Barr $(1998,1999)$, and we here provide additional information to establish it as a formal unit. Contacts between the Clam Harbour River, Tracadie Road, and Caledonia Mills formations are generally conformable and gradational, and overall younging direction is to the northwest. However, facing directions are in many places difficult to determine and the structure in the area is complicated by faults and polyphase folding (see below). A fourth formation (Steep Creek), identified and named informally by Ténière (2002) and Ténière et al. (2002), occurs along the eastern margin of the area and has an uncertain relationship to the other units. We propose here that the Steep Creek Formation, as described below, also be designated as a formal stratigraphic unit.

Fossils are rare in these rocks, at least in part due to the presence of well developed cleavage. Lepidodendropsis fragments were reported previously in dark grey shale assigned here to the Tracadie Road Formation (Schiller 1961; Smith 1980, 1981), and also were observed in that unit during the present study (Ténière 2002). According to Wagner (1984), Lepidodendropsis occurred most commonly in the Early Carboniferous, between the Tournaisian and Early Visean, but may have originated during the late Famennian (Devonian). Spores have been found in a few locations, but are poorly preserved as a result of high thermal maturity (Utting 2001). Six samples collected during this study, five from the Tracadie Road Formation and one from the Steep Creek Formation, contained three spore species that are long-ranging, but dominantly Tournaisian, and hence suggest the age of the rocks to be Late Devonian (Famennian) to late Tournaisian(Utting 2001; Ténière 2002).

\section{Clam Harbour River Formation}

Rocks assigned to the Clam Harbour River Formation occur in the eastern part of the map area between Lincolnville and the Strait of Canso (Fig. 2). The name was assigned by Smith $(1980,1981)$, based on exposures of green-grey siltstone and shale, with interbedded dolomite, that occur in Clam Harbour River. White and Barr $(1998,1999)$ extended the distribution of the formation over a more extensive area than that studied by Smith $(1980,1981)$, and during the present study, the formation was subdivided into two informal members, the predominantly coarse-grained Englands Lake member and the fine-grained Goose Harbour Lake member.

The Englands Lake member is exposed in the eastern part of the map area in the core of an anticlinal structure (Fig. 2). Based on the interpreted geological cross section (Ténière 2002), the member has a minimum thickness of $600 \mathrm{~m}$, with the base not exposed. As best seen in the type area northwest of Englands Lake, it consists of polymictic and matrix-supported conglomerate, light grey, fine- to coarse-grained sandstone (fining-upward sequences; Fig. 3), and interbedded maroon to green-grey siltstone. The Englands Lake member is interpreted to have formed in a high gradient, braided fluvial system on the distal parts of alluvial fan(s). The conformably overlying (but possibly in part laterally equivalent) Goose Harbour Lake member has an estimated thickness between 700 and $1000 \mathrm{~m}$. It consists of poorly to well laminated (varve-like) green-grey siltstone and shale with interbedded quartz-rich sandstone and calcareous fine-grained sandstone. The type section is located on the southern shore of Goose Harbour Lake (Fig. 2). These rocks are interpreted to have been deposited in a shallow lacustrine to shoreline environment, based on the dominantly greenish-grey colour and minor red siltstone beds, which suggest occasional oxidizing conditions. The Goose Harbour Lake member is conformably overlain by the Tracadie Road Formation, unconformably overlain by the Steep Creek Formation, and in faulted contact with younger Carboniferous units (Fig. 2). 


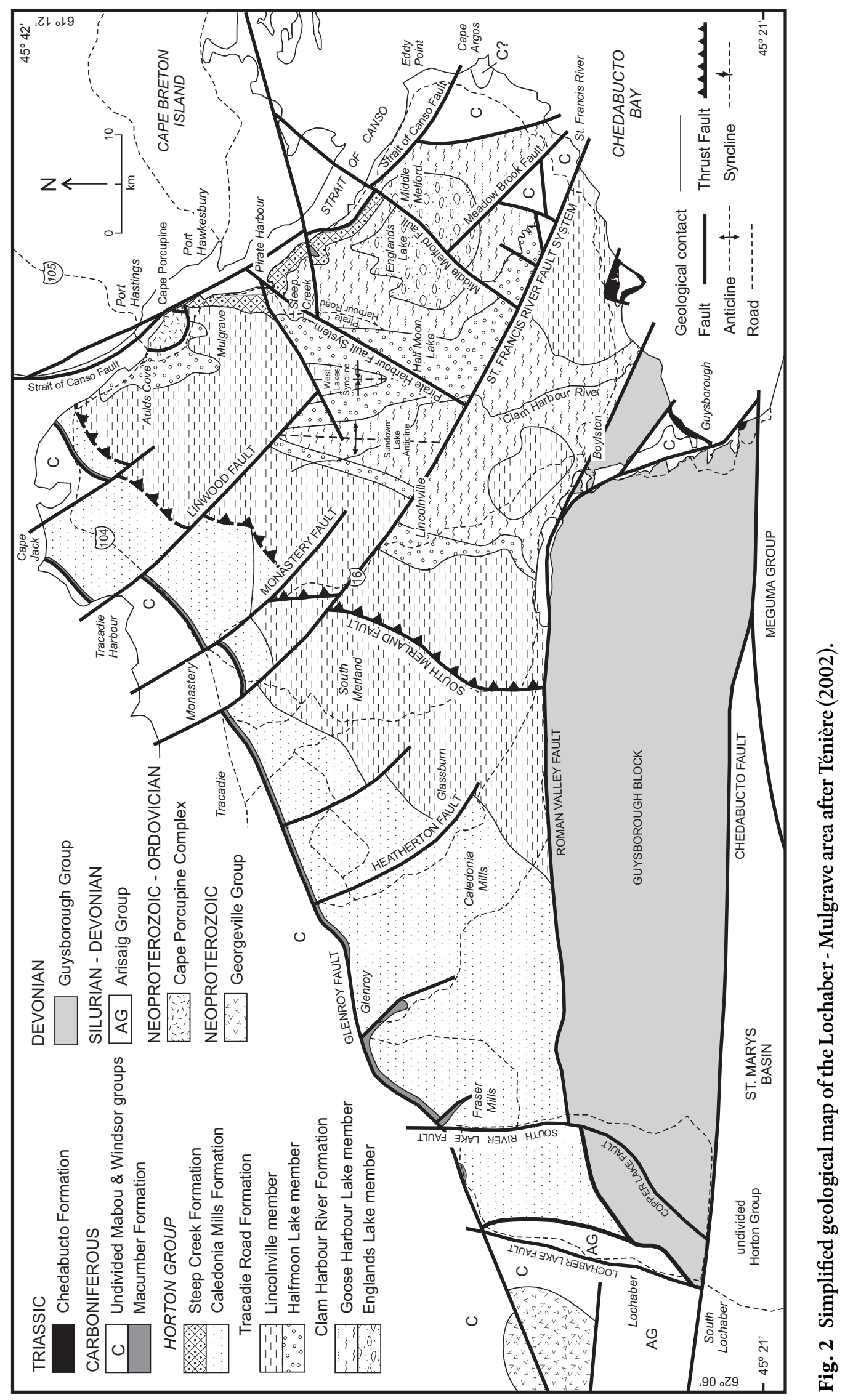




\section{Tracadie Road Formation}

Rocks assigned to the Tracadie Road Formation underlie the northeastern and central parts of the map area between the Strait of Canso and the Roman Valley Fault (Fig. 2). The name was assigned by Smith $(1980,1981)$ to well cleaved siltstone that outcrops along Highway 16 between Boyleston and Tracadie. White and Barr $(1998,1999)$ extended the distribution of the formation beyond the area studied by Smith $(1980,1981)$. Two informal members were recognized during the present study, a lower, coarser grained Halfmoon Lake member, and an overlying finer-grained Lincolnville member. The Halfmoon Lake member is in gradational contact with the underlying Goose Harbour Lake member of the Clam Harbour River Formation, and has a thickness of 600 to $1000 \mathrm{~m}$, estimated from the geological cross section (Ténière 2002). Typical exposures occur on the old Pirate Harbour Road, north of Halfmoon Lake (Fig. 2 ). The member generally fines upward from coarse pebble conglomerate into light grey pebble sandstone and dark grey siltstone. The dominantly coarse-grained lithologies and wellrounded pebble clasts in the conglomerate suggest a fluvial environment of deposition. In contrast to the high-energy environment represented by the underlying Goose Harbour Lake member, the Halfmoon Lake member was probably deposited in a lower gradient system, distal to alluvial fan(s).

The Lincolnville member conformably overlies the Halfmoon Lake member and is one of the most areally extensive units in the map area (Fig. 2). It is well exposed along the Highway 16 between Boylston and Lincolnville, and has a minimum estimated thickness of $750 \mathrm{~m}$. The lower part of the member consists of dark grey to black laminated siltstone and shale interbedded with quartz arenite. The upper part is a mainly coarser succession of medium-grained to pebble sandstone, minor dark grey siltstone, and rare conglomerate (Fig. 4). The siltstone and shale contain rare Lepidodendropsis plant fragments and spores. Detrital muscovite is common in fine- to medium-grained sandstone, especially from areas adjacent to the Cape Porcupine Complex. The Lincolnville member was probably deposited in a lacustrine environment, with the lower succession formed in deeper water, below wave base, and the upper succession deposited above wave base in the near-shore to shoreline environment.

\section{Caledonia Mills Formation}

Rocks assigned to the Caledonia Mills Formation underlie the northwestern part of the map area adjacent to the Glenroy Fault between the Strait of Canso and Fraser Mills (Fig. 2). The name was assigned to rocks in this area by White and Barr $(1998,1999)$. No fossils have been found in the Caledonia Mills Formation to constrain its age, but it is assigned to the Horton Group on the basis of its concordant relationship with the underlying Tracadie Road Formation, and the local presence of overlying Macumber Formation of the Visean Windsor Group (Fig. 2). The contact with the Macumber Formation is interpreted to be unconformable. In the Lochaber area, the Caledonia Mills Formation is inferred to be in faulted contact with the Knoydart Formation of the Silurian - Devonian Arisaig Group (Fig. 2).

The Caledonia Mills Formation has an estimated thickness of 1500 to $3250 \mathrm{~m}$ based on the interpreted geological cross section (Ténière 2002). It consists of maroon to light grey, massive to well-laminated siltstone, shale, sandstone, and conglomerate. The lower part of the formation is dominantly fine grained

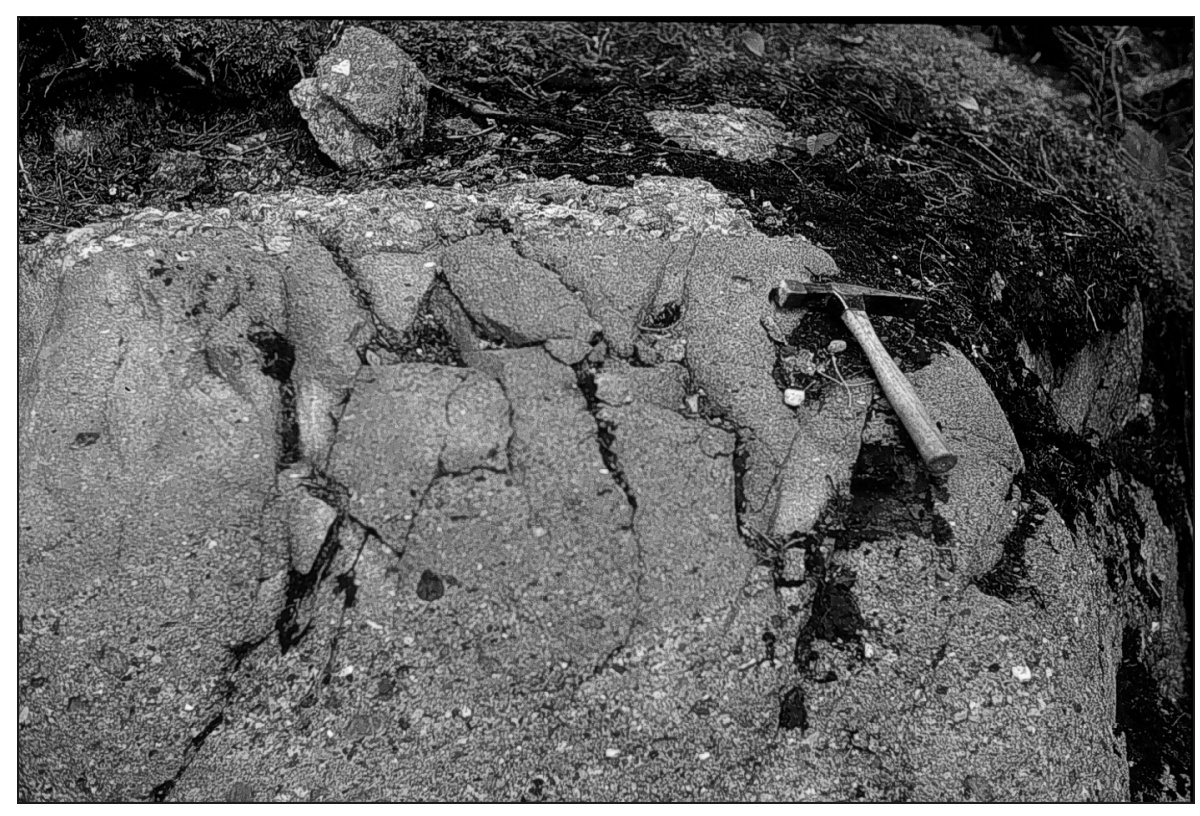

Fig. 3 Fining upward sequence of conglomerate to pebble sandstone to sandstone in the Englands Lake member of the Clam Harbour River Formation. 


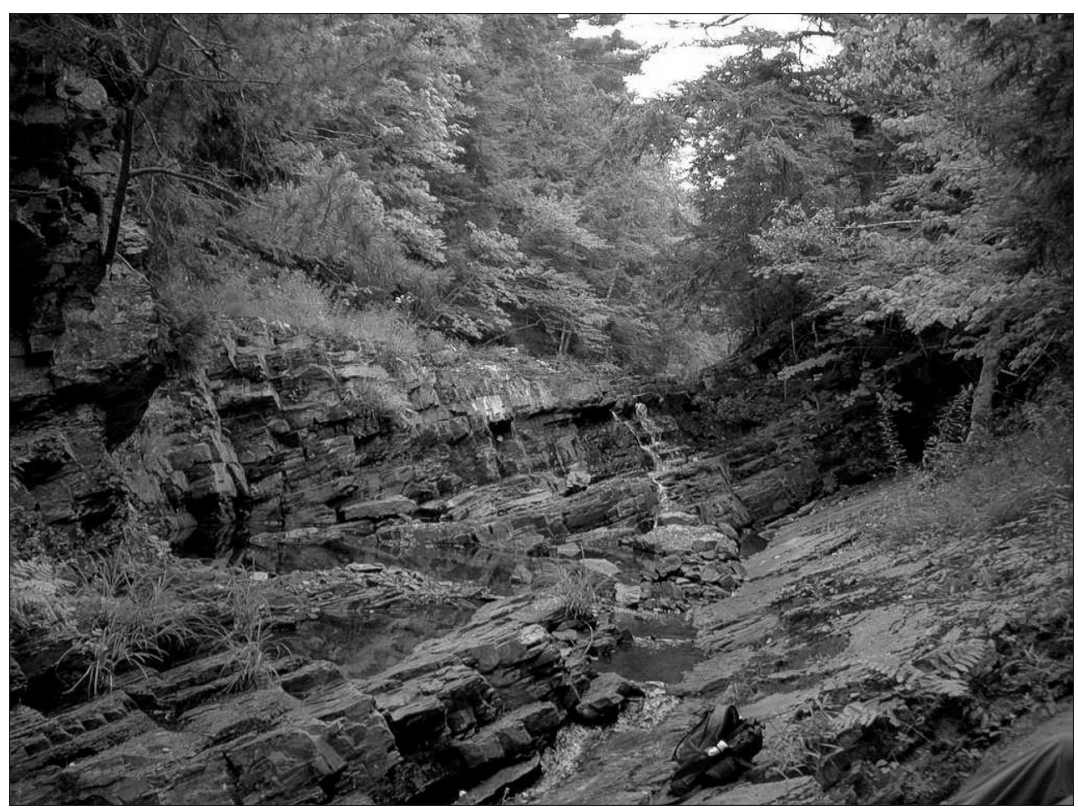

Fig. 4 Grey, fine-grained sandstone, siltstone, and shale typical of the upper part of the Lincolnville member of the Tracadie Road Formation in the Lochaber-Mulgrave area.

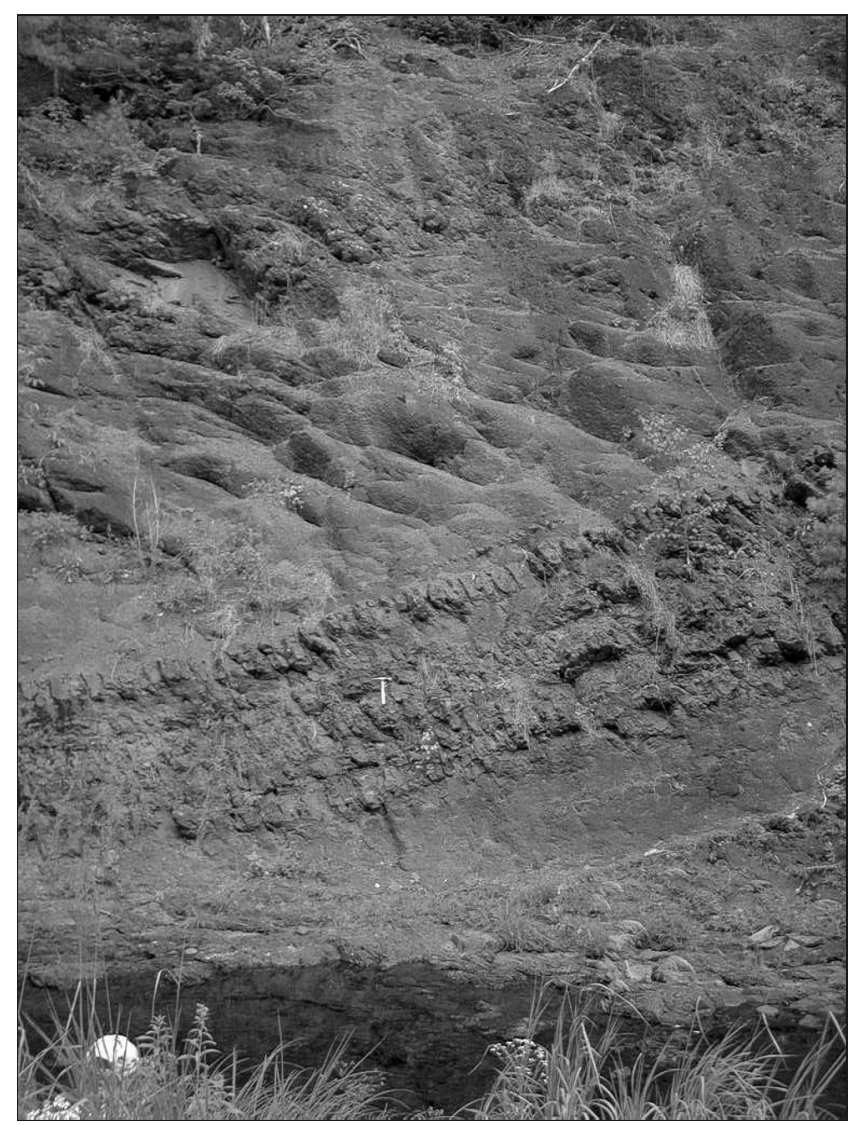

Fig. 5 Red siltstone and interbedded fine sandstone typical of the Caledonia Mills Formation in the Lochaber-Mulgrave area. and consists of weakly laminated and cleaved maroon and green-grey siltstone and shale with thin interbeds of light grey quartz arenite. In the upper part, siltstone units reach a thickness of 8-12 $\mathrm{m}$ and are interbedded with fluviatile sandstone and conglomerate layers of variable thickness (Fig. 5). Rarely, root traces and poorly developed calcrete horizons are present. Small flakes ( $<1 \mathrm{~mm}$ in length) of detrital muscovite are visible on the bedding planes of maroon and light grey sandstone units. The type section for the Caledonia Mills Formation on Black Avon River is typical of the upper part of the formation, and includes an approximately $100 \mathrm{~m}$-thick section of well laminated fine- to medium-grained light grey sandstone units about $10 \mathrm{~m}$ thick, interbedded with maroon siltstone units about 8-10 m thick. The Caledonia Mills Formation is interpreted to represent deposition in a fluvial environment. The dominantly red colour and lack of plant remains or roots may indicate deposition in a semi-arid climate. The lack of thick, homogeneous channel sandstone and conglomerate units and a high proportion of overbank deposits suggest deposition in an anastomosing river system (Miall 1992).

\section{Steep Creek Formation}

Rocks assigned to the Steep Creek Formation occur in the eastern part of the map area along the Strait of Canso, and the type section designated here is in Steep Creek (Fig. 2). This unit has an estimated thickness of 500 to $750 \mathrm{~m}$ and unconformably overlies both the Lincolnville and Goose Harbour Lake members of the Tracadie Road and Clam Harbour River formations, Like the Caledonia Mills Formation, the Steep Creek Formation underlies the Macumber Formation, and it may be facies equivalent to the upper part of the Caledonia 
Mills Formation, but confirming this relationship is difficult. A sample from the Steep Creek Formation yielded a spore assemblage that suggests a Tournaisian age (Utting 2001; Ténière 2002), whereas no spores were recovered from the Caledonia Mills Formation.

The lower part of the Steep Creek Formation consists of light grey polymictic conglomerate with angular clasts, pebble sandstone, fine-grained laminated sandstone, and interbedded red siltstone, whereas the upper part consists of red and dark grey siltstone and shale, which coarsen upward into a thick, cross-bedded channel sandstone. The lower part of the formation may represent braided-fluvial deposition in an alluvial plain, whereas the upper unit may reflect a transition from alluvial-plain to delta-plain and shallow-lacustrine depositional environments (Miall 1992). The type section of the formation occurs in Steep Creek where a section several hundred metres in thickness consists of mainly fine-grained sandstone, siltstone, and shale typical of the lower part of the formation. The coarse upper part of the formation is well exposed in quarries in the same area.

\section{STRUCTURAL GEOLOGY}

Because of the large size of the map area, structural features from the western, central, southeastern, and northeastern parts are illustrated and described separately (Figs. 6a-d). The boundary between area (b) and areas (c) and (d) is placed at the South Merland Fault, which corresponds to a linear feature on digital elevation models (Ténière 2002). This inferred thrust fault explains the dramatic change in unit thickness along strike from southwest to northeast across the central part of the map area.

The westernmost part (a) includes the Caledonia Mills Formation between the faulted boundary with the Arisaig Group to the west and the South River Lake Fault to the east. Bedding orientations in that area (although scattered) generally trend northeast and are vertical or dip steeply to the southeast (Fig. 6a, upper diagram). Slaty cleavage is moderately well developed in fine-grained lithologies and generally trends north and dips steep to the east (Fig. 6a, lower diagram). Although

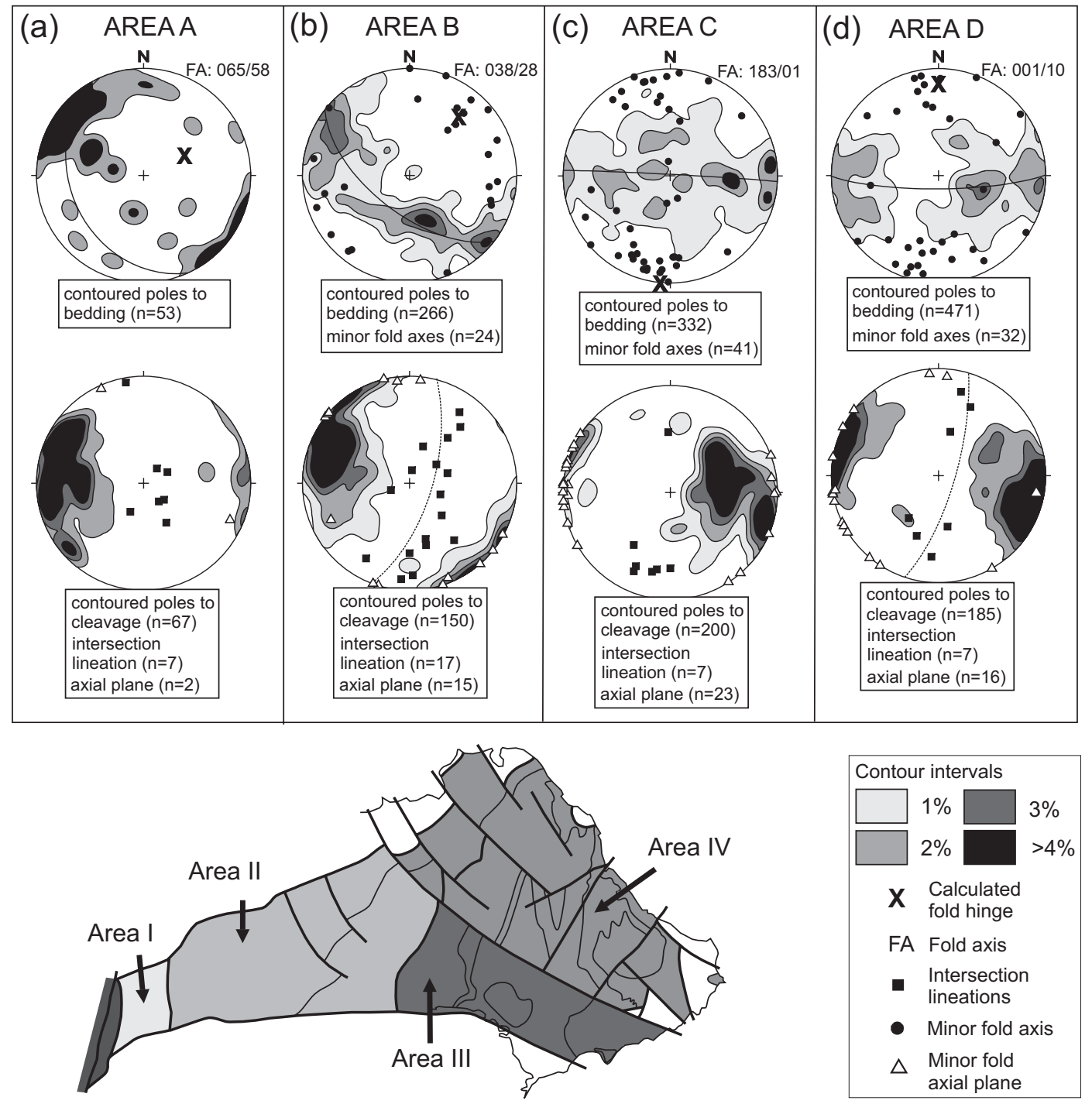

Fig. 6 Summary of structural data from domains IIV, as described in the text. 
at least some of the cleavage may have been axial planar in origin, it likely has been strongly overprinted or re-orientated by movements associated with the South River Lake and Lochaber faults, as cleavage tends to be vertical near these faults. Intersection lineations (Fig. 6a, lower diagram) are evident only as near-vertical colour banding on cleavage planes.

Area (b) to the east includes parts of the Caledonia Mills and Tracadie Road formations between the South River Lake and South Merland faults and the Glenroy and Roman Valley faults. Bedding trends are similar to those in area (a), but dips vary from shallow to steep and define a better 'girdle' distribution with a shallow northeast-plunging fold axis (Fig. 6b, upper diagram). Northeast-trending, vertical to steeply southeast-dipping cleavage is well developed and, in contrast to area (a), is axial planar to the regional folds. Although the data display some scatter, minor folds and associated axial planes are mainly parallel to the regional fold axis (Fig. 6b). Bedding-cleavage intersection lineations define a girdle distribution that dips steeply to the southeast, subparallel to the cleavage (Fig. 6b, lower diagram).

Area (c) includes units of the Tracadie Road and Clam Harbour River formations between the South Merland, Roman Valley, and St. Francis River faults. In comparison to those in the area to the west, bedding orientations are much more scattered; however, they indicate a sub-horizontal to very shallow north- and south-plunging fold axis (Fig. 6c, upper diagram). Bedding generally strikes north, but changes orientation near the Roman Valley and St. Francis River faults to become subparallel to those features. Axial planar cleavage also strikes north and is steep to west dipping; however, the vergence of these folds is opposite to that of folds in area (b). Minor folds (and associated axial planes) and intersection lineations mimic the regional fold geometry (Fig. 6c). In both areas (b) and (c), large-scale folds trend northeast to north, whereas regional-scale folds are not evident in area (a). Evidence for at least locally intense deformation (tight to isoclinal folds) was observed in siltstone and shale of the Goose Harbour Lake and Lincolnville members.

In the northeastern part of the map area $(d)$, bedding orientations are scattered but sub-horizontal to shallow north-and south-plunging folds are present, as in area (c) (Fig. 6c, upper diagram). Cleavage orientations (Fig. 6d, lower diagram) are also slightly scattered, but on average strike south to southwest with vertical to steep dips to the west and appear to be axial planar to regional folds. Minor folds (and associated axial planes) and intersection lineations mimic the regional fold geometry (Fig. 6d). Bedding and cleavage orientations become sub-parallel to the St. Francis River Fault and to northwest-trending faults in the northern part of the map area. South of the Cape Porcupine Complex, the Tracadie Road and Clam Harbour River formations are deformed in the north-plunging West Lakes Syncline and Sundown Lake Anticline (Fig. 2). A series of north-plunging en echelon anticlinal and synclinal closures occur in the Goose Harbour Lake and Englands Lake members, northwest of the Middle Melford Fault (Fig. 2).

The dominantly northeast-trending fold patterns and the inferred presence of several west-directed, north- to northeast-trending thrust faults are consistent with major dextral displacement along the Cobequid-Chedabucto-Roman Valley fault system. The presence of well developed axial planar cleavage indicates that deformation was broadly synchronous with low-grade regional metamorphism.

In contrast to the Horton Group, rocks in the younger Visean and Early Namurian Windsor and Mabou groups are less deformed. In the northern part of the map area near the Glenroy Fault and in the Strait of Canso area, these units are tilted, not folded, and lack cleavage development. However, in the southern part of the map area (St. Francis River area), these younger units are intensely folded and locally well cleaved. This deformation may have been related to continued movement along the Cobequid-Chedabucto-Roman Valley fault system during the Late Carboniferous and Mesozoic. This later deformation also included the development of several northwesttrending transcurrent faults that cut the Horton, Windsor, and Mabou groups. These structures did not produce major folding in the adjacent units, and may have formed as transfer faults associated with the opening of the Atlantic Ocean during the Mesozoic (Williams et al. 1995). Faulted boundaries of the Triassic Chedabucto Formation (Fig. 2) may record even later motion in the Cobequid-Chedabucto fault zone.

\section{METAMORPHISM}

The Horton Group in the Lochaber-Mulgrave area has undergone low-grade (sub-greenschist facies) metamorphism synchronous with regional deformation. In many slate samples, fine-grained white muscovite with a preferred orientation defines a regional cleavage. However, no higher grade metamorphic minerals were observed, and intensity of cleavage development varies over the map area and with rock type. For example, a well-developed foliation is present throughout the southern part of the map area in fine-grained rocks of the Tracadie Road Formation. The Lincolnville member includes slate with a strong slaty cleavage, interbedded with essentially uncleaved quartz arenite. The degree of cleavage development decreases northward toward the Glenroy Fault, and generally is poorly developed in the Caledonia Mills Formation. Cleavage development is strongest adjacent to and north of the Roman Valley Fault, and near the Lochaber Lake and South River Lake shear zones. Other evidence for metamorphism is the high thermal maturity in the Horton Group, as well as in parts of the Mabou Group (Utting 2001). Spores are typically cooked beyond the point of identification. Many of these rocks have matured beyond the dry gas preservation zone (thermal alteration index of 4 to 5) and have high vitrinite reflectance values $($ Ro\% $=3.5)$. Rocks with a vitrinite reflectance of 3.5 or higher were possibly buried as deep as $8 \mathrm{~km}$, with temperatures reaching $>300^{\circ} \mathrm{C}$ (Frey and Robinson 1999).

The metamorphism and associated cleavage development are interpreted to have taken place during post-depositional burial and compression. The time of regional metamorphism 
is constrained to about $340-335$ Ma by whole-rock ${ }^{40} \mathrm{Ar} /{ }^{39} \mathrm{Ar}$ spectra from well-cleaved slate samples from the Clam Harbour River and Tracadie Road formations (Reynolds et al. 2004). This age is similar to the age of the rocks themselves, and hence burial diagenesis was probably nearly synchronous with tectonic activity. This 340-335 Ma tectonothermal event may have been the result of burial by older volcanic and sedimentary rocks of the Guysborough Group (see Tectonic Evolution in the Discussion).

\section{DISCUSSION}

\section{Regional Correlations}

The Horton Group is commonly regarded as an intracontinental, fluvial to lacustrine basin-fill sequence that oversteps terrane boundaries in the northeastern Appalachian orogen (Calder 1998). In mainland Nova Scotia, the basin-fill sequence rests on rocks of both the Meguma and Avalon terranes, which were brought into juxtaposition along the Cobequid-Chedabucto fault system during the Devonian. Seismic profiles and sedimentary evidence at many localities in Atlantic Canada indicate that Horton Group strata occupy local half grabens with varied polarity. Martel and Gibling (1991) proposed that the Horton Group in the type area was laid down in a half graben during syn-depositional extension along the Cobequid-Chedabucto, or precursor, fault system. The depositional sequence in each subbasin typically consists of (i) a thick basal coarse-grained alluvial succession that rests unconformably on older basement rock, overlain by (ii) a dark-grey, fine-grained lacustrine succession, which is overlain conformably to unconformably by (iii) an upper coarse- to finegrained alluvial succession.

In its type area, the Horton Group is divided into the Horton Bluff and Cheverie formations (Bell 1929, 1960). Martel and Gibling (1996) subdivided the Horton Bluff Formation into (1) the Harding Brook Member, which unconformably overlies the Lower Paleozoic Meguma Group and represents the basal alluvial sequence, (2) the Curry Brook, Blue Beach and Hurd Creek members which represent the lacustrine sequence, and (3) the Cheverie Formation which represents the upper fluvial sequence. Detailed mapping, as well as sedimentological and paleontological studies, suggest a latest Devonian (Famennian) to Tournaisian age for the Horton Bluff Formation and a latest Tournaisian age for the Cheverie Formation (Martel and Gibling 1996). Comparing units in the Lochaber-Mulgrave area to those in the type area, the Clam Harbour River Formation is broadly similar to the Harding Brook Member as both units consist of a basal alluvial sequence that fines upward into lacustrine-deposited mudstone. The Halfmoon Lake member is similar to the Curry Brook Member, as both contain coarsening-upward shale to sandstone sequences deposited in fluvial-lacustrine environments. The Lincolnville member is similar to the Blue Beach Member, as both units contain dark-grey shale and siltstone deposited in a lacustrine setting, and Lepidodendropsis plant material. The Caledonia Mills Formation is similar to the Cheverie Formation, as both units are coarse grained and have channel and red floodplain deposits (overbank) with minor calcrete. Although the units of the Lochaber-Mulgrave area are lithologically similar to those in the type area, they cannot be precisely correlated due to the lack of well-preserved spore assemblages. Sparse spores from the Tracadie Road and Steep Creek formations indicate that the Horton Group in the Lochaber-Mulgrave area was deposited by the mid-Tournaisian $\left(\mathrm{T}_{2}\right)$ (Utting 2001), whereas in the type area, the Horton Group was deposited between the latest Devonian and Late Tournaisian $\left(\mathrm{T}_{3}\right)$ (Martel and Gibling 1996). The $340-335 \mathrm{Ma}^{40} \mathrm{Ar} /{ }^{39} \mathrm{Ar}$ age from whole-rock samples of the Clam Harbour River and Tracadie Road formations (Reynolds et al. 2004) provide a minimum age for the Horton Group in the Lochaber-Mulgrave area, which approximately coincides with the Tournaisian-Visean boundary, now set at $342 \pm 3 \mathrm{Ma}$ (Okulitch 2002).

The St. Marys Basin occupies the present boundary between the Avalon and Meguma terranes in central mainland Nova Scotia, southwest of the study area (Fig. 1). Murphy and Rice (1998) defined six formations in the Horton Group of the St. Marys Basin that they interpreted to be broadly coeval and in large part facies equivalents of one another. Only two of the three typical lithological successions of the Horton Group appear to be represented in the St. Marys Basin. The Little Stewiacke River Formation, which consists of 800-950 m of interstratified, thinly bedded mudstone, fissile light- to dark-grey and black shale and siltstone, and minor sandstone containing plant debris (Murphy and Rice 1998; Murphy and Hamilton 2000), may equate with the middle lacustrine unit, and hence be broadly correlative with the Tracadie Road Formation. The overlying Graham Hill, Barrens Hills, and Lochiel formations likely represent the upper alluvial succession and in part resemble the Caledonia Mills and Steep Creek formations of the Lochaber-Mulgrave area. Other units (Cross Brook and West River St. Marys formations) do not appear to be represented in the type area of the Horton Group, and may be localized at the southern (Meguma terrane) margin of the St. Marys Basin. Murphy and Rice (1998) suggested that the Chedabucto Fault may not represent the original northern margin of the basin and an unknown portion of the original basin may have been tectonically removed by Late Carboniferous movement along the fault. This interpretation suggests that units formed in the St. Marys Basin may occur north of the present Chedabucto Fault. The Horton Group strata in the Lochaber-Mulgrave area may have originally been deposited in the same basin as strata in the St. Marys Basin, but more detailed comparisons are required to further investigate this possibility.

In western Cape Breton Island, the three lithological successions of the Horton Group are represented by the Creignish, Strathlorne, and Ainslie formations (Hamblin and Rust 1989; Giles et al. 1997a, b, c). Spore assemblages from the upper part of the Creignish Formation are of Tournaisian $\left(\mathrm{T}_{2}\right)$ age and those from the Strathlorne and Ainslie formations are of late $\mathrm{T}_{2}$ to mid $\mathrm{T}_{3}$ age (Utting and Hamblin 1991). These dominantly 
mid to late Tournaisian spore assemblages suggest that these formations in western Cape Breton Island may be younger than those in the Lochaber-Mulgrave area, although comparisons with descriptions by Hamblin and Rust (1989) and Giles et al. (1997a, b, c) suggest that they are lithologically similar. The Englands Lake member resembles the Creignish Formation, as both contain alluvial fan conglomerate and red to green-grey siltstone and sandstone. The Goose Harbour Lake member is similar to the lower part of the Strathlorne Formation, as both contain green-grey siltstone and mudstone and minor red siltstone and sandstone. The Halfmoon Lake member is lithologically similar to the middle part of the Strathlorne Formation, where pebbly sandstone and matrix-supported conglomerate occur in sections interpreted to have formed proximal to fault margins (Hamblin and Rust 1989). The lacustrine shale of the Lincolnville member is similar to rocks in the upper part of the Strathlorne Formation, and the Caledonia Mills Formation is similar to the Ainslie Formation, both being dominated by fluvial red beds. The Steep Creek Formation does not appear to be represented in western Cape Breton Island, but may be a lateral facies equivalent of the Caledonia Mills/Ainslie Formation.

\section{Tectonic Evolution}

The Horton Group in the Lochaber-Mulgrave area is interpreted to have been deposited between the Late Devonian (Famennian) and Early Carboniferous (Tournaisian) in a half graben during syn-depositional extension(transtension) along the Cobequid-Chedabucto fault system at the boundary between the Avalon and Meguma terranes. The half-graben may have been continuous with that in which units in the area now known as the St. Marys Basin were deposited. A basal coarse, alluvial succession (Englands Lake member) was unconformably deposited over basement, the latter possibly represented in part by the Cape Porcupine Complex (White et al. 2001). Petrographic studies of typical samples from throughout the Horton Group in the Lochaber-Mulgrave area show that the sediments are relatively immature, with abundant feldspar and muscovite (Ténière 2002). Granitic clasts in the Tracadie Road Formation in the vicinity of the Cape Porcupine Complex suggest that the latter may have been the source area. However, single-grain fusion analysis of detrital muscovite from samples in that area yielded ${ }^{40} \mathrm{Ar} /{ }^{39} \mathrm{Ar}$ ages mainly in the range 410 $380 \mathrm{Ma}$, significantly older than muscovite from the Cape Porcupine Complex which yielded ca. $365 \mathrm{Ma}{ }^{40} \mathrm{Ar} /{ }^{39} \mathrm{Ar}$ plateau ages (Reynolds et al. 2004). Overall, the ${ }^{40} \mathrm{Ar} /{ }^{39} \mathrm{Ar}$ ages from detrital muscovite in samples from the Lochaber-Mulgrave area data indicate that the Meguma terrane was probably the source of most sediment (Reynolds et al. 2004), as also suggested by detrital zircon studies in St. Marys Basin (Murphy and Hamilton 2000).

The Horton Group in the Lochaber - Mulgrave area was buried rapidly after deposition and was deformed and metamorphosed by ca. $340-335 \mathrm{Ma}$, as indicated by ${ }^{40} \mathrm{Ar} /{ }^{39} \mathrm{Ar}$ ages from the Clam Harbour River and Tracadie Road formations (Reynolds et al. 2004). This rapid burial and deformation may have been caused by thrust sheets originating from the south in a positive flower structure at a restraining bend along the Cobequid-Chedabucto fault system (Webster et al. 1998). The Devonian volcanic and sedimentary rocks exposed in the "Guysborough block" between the Roman Valley and Chedabucto faults may represent a tectonically uplifted block associated with this positive flower structure, and the Roman Valley Fault may represent the trace of a northward-directed thrust fault that buried the Horton Group in the adjacent Lochaber-Mulgrave area, thereby causing folding and regional metamorphism. Although Webster (1996) and Webster et al. (1998) suggested that flower structure developed during the Late Carboniferous (Westphalian C-D), by analogy with similar deformation at that time in southern New Brunswick (Nance, 1987), our data and those of Reynolds et al. (2004) suggest that it occurred earlier, at about $340-335 \mathrm{Ma}$; however, movement likely continued into the Late Carboniferous as dextral transpressive displacement along the ChedabuctoRoman Valley fault system. Folding and faulting in the Visean to Namurian Windsor and Mabou groups in the LochaberMulgrave map area are evidence for on-going deformation. Thermal maturity of these units in the St. Francis River area (Utting 2001) may be due to hot fluids originating from the still-active Roman Valley fault system and moving through these units in the Late Carboniferous. In contrast, the Windsor and Mabou groups in the northern part of the map area (north of the Glenroy Fault) are less deformed and have lower thermal maturities.

\section{CONCLUSIONS}

Detailed mapping combined with fossil evidence, albeit sparse, has confirmed that most rocks in the LochaberMulgrave area are part of the Horton Group. The sedimentary sequence is approximately $4000 \mathrm{~m}$ thick and is divided into four formations (oldest to youngest): (i) Clam Harbour River Formation (Englands Lake and Goose Harbour Lake members), (ii) Tracadie Road Formation (Halfmoon Lake and Lincolnville members),(iii) Caledonia Mills Formation, and (iv) Steep Creek Formation. Rocks of these units were deposited variously in braided fluvial and shallow to deep lacustrine environments. In comparison to other areas, the Horton Group in the Lochaber-Mulgrave area is more complexly deformed and metamorphosed. Deformation was more intense in proximity to major faults, especially the Roman Valley-Chedabucto fault system in the south. Paleontological constraints suggest that the Horton Group in the Lochaber-Mulgrave area was deposited during latest Devonian (Famennian) and early to mid Tournaisian, perhaps in a shorter time interval than were Horton Group rocks in their type area. The rocks were rapidly buried, deformed and metamorphosed, then uplifted by about $340-335 \mathrm{Ma}$, based on ${ }^{40} \mathrm{Ar} /{ }^{39} \mathrm{Ar}$ whole-rock dating, prior to deposition of the Visean Macumber Formation. It is postulated that burial and deformation resulted from thrust sheets originating from a positive flower structure along the 
Avalon-Meguma terrane boundary to the south. Subsequent uplift and deformation were related to on-going movement on the terrane boundary and related faults.

\section{ACKNOWLEDGEMENTS}

This work formed part of a MSc thesis at Acadia University by Paul Ténière. Field assistance was ably provided by Jennifer Ferris, Dallas MacIsaac, and John Ténière. Field studies were funded in large part by the Nova Scotia Department of Natural Resources and Geological Survey of Canada through a Targeted Geoscience Initiative. Additional financial support for the project was provided by Natural Sciences and Engineering Research Council of Canada discovery grants to Sandra Barr.

We are grateful to Peter Giles of the Geological Survey of Canada (Atlantic) and Rob Naylor of the Nova Scotia Department of Natural Resources for their invaluable advice and help in the field, and in comparisons between stratigraphic units in the study area and those elsewhere in the region. Peter Reynolds and Keith Taylor provided ${ }^{40} \mathrm{Ar} /{ }^{39} \mathrm{Ar}$ data which provided constraints on sediment provenance and on timing of metamorphism, data crucial to interpretations presented here. We thank journal reviewers Tony Hamblin and Brendan Murphy, as well as the editor Rob Fensome, for their helpful suggestions and advice that resulted in a much improved manuscript.

\section{REFERENCES}

Barr, S.M., Raeside, R.P., \& White, C.E. 1998. Geological correlations between Cape Breton Island and Newfoundland. Canadian Journal of Earth Sciences 35, pp. 1252-1270.

BELL, W.A. 1929. Horton-Windsor District, Nova Scotia. Geological Survey of Canada, Memoir 155. 268 p.

BELL, W.A. 1960. Mississippian Horton Group of the Type Windsor-Horton District, Nova Scotia. Geological Survey of Canada, Memoir 314. 112 p.

Boenner, R.C., \& Giles, P.S. 1993. Geology of the Antigonish Basin, Antigonish County, Nova Scotia. Nova Scotia Department of Natural Resources, Mines and Energy Branch, Memoir 8.

Calder, J.H. 1998. The Carboniferous evolution of Nova Scotia. In Lyell: the Past is the Key to the Present. Edited by D.J. Blundell \& A.C. Scott, Geological Society, Special Publications 143, pp. 261-302.

Cormier, C.F.M., Barr, S.M., \& DunNing, G.R. 1995. Geological setting and petrochemistry of early Middle Devonian volcanic and gabbroic rocks in the Guysborough area, Nova Scotia. Atlantic Geology, 31, pp. 153-166.

Frey, M., \& Robinson, D. 1999. Low-grade metamorphism. Blackwell Science, Oxford, England. 313 p.

Giles, P.S., Hein, F.J., \& Allen, T.L. 1997a. Bedrock geology of Port-Hood-Lake Ainslie (11K/04, 11K/03, 11F/13), Cape
Breton Island, Nova Scotia. Geological Survey of Canada, Open File 3253, scale 1:50 000, map with marginal notes.

Giles, P.S., Hein, F.J., \& Allen, T.L. 1997b. Bedrock geology of Margaree (11K/06), Cape Breton Island, Nova Scotia. Geological Survey of Canada, Open File 3254, scale 1:50 000, map with marginal notes.

Giles, P.S., Hein, F.J., \& Allen, T.L. 1997c. Bedrock geology of the Cheticamp map area, Cape Breton Island, Nova Scotia. Geological Survey of Canada, Open File 3255, scale 1:50 000, map with marginal notes.

Hamblin, A.P., \& Rust, B.R. 1989. Tectono-sedimentary analysis of alternate-polarity half-graben basin fill successions: the Late Devonian-Early Carboniferous Horton Group, Cape Breton Island, Nova Scotia, Canada. Basin Research, 2, pp. 239-255.

KePpiE, J.D. 1979. Geological map of the province of Nova Scotia. Nova Scotia Department of Natural Resources, scale 1:500 000 .

Keppie, J.D. (Compiler) 2000. Geological map of the province of Nova Scotia. Nova Scotia Department of Natural Resources and Energy, Map ME2000-1. Scale 1:500,000.

Lynch, G., \& GiLEs, P.S. 1995. The Ainslie Detachment: a regional flat-lying extensional fault in the Carboniferous evaporitic Maritimes Basin of Nova Scotia, Canada. Canadian Journal of Earth Sciences, 33, pp. 169-181.

Martel, A.T., \& Gibling, M.R. 1991. Wave-dominated shoreline facies and tectonically controlled cyclicity of the Lower Carboniferous Horton Bluff Formation, Nova Scotia, Canada. In Lacustrine Facies Analysis. Edited by P. Anadon, L. Cabrera, \& K. Kelts. International Association of Sedimentologist, Special Publication 13, pp. 223-243.

Martel, A.T., \& Gibling, M.R. 1996. Stratigraphy and tectonic history of the Upper Devonian to Lower Carboniferous Horton Bluff Formation, Nova Scotia. Atlantic Geology, 32, pp. 13-38.

Miall, A.D. 1992. Alluvial deposits. In Facies models, response to sea level change. Edited by R. Walker \& N.P. James. Geological Association of Canada. pp. 119-142.

MurPhy, J.B., \& HAMiLton, M.A. 2000. Orogenesis and basin development: $\mathrm{U}-\mathrm{Pb}$ detrital zircon age constraints on evolution of the Late Paleozoic St. Marys Basin, central mainland Nova Scotia. Journal of Geology, 108, pp. 53-71

MurPhy, J.B., \& Rice, R.J. 1998. Stratigraphy and depositional environment of the Horton Group in the St. Marys Basin, central mainland Nova Scotia. Atlantic Geology, 34, pp. $1-25$.

Murphy, J.B., Keppie, J.D., \& Hynes, A.J. 1991. The geology of the Antigonish Highlands, Nova Scotia. Geological Survey of Canada, Paper 89-10.

NANCE, R.D. 1987. Dextral transpression and Late Carboniferous sedimentation in the Fundy Coastal Zone of southern New Brunswick. In Sedimentary Basins and Basin-forming Mechanisms. Edited by C. Beaumont \& A.J. Tankard. Canadian Society of Petroleum Geologists, Memoir 12, pp. 363-377.

Oкuliтch, A.V. 2002. Geological time scale. Geological 
Survey of Canada, Open File 3040, National Earth Science Series, Geological Atlas - Revision.

Reynolds, P.H., Barr, S.M., White, C.E., \& Ténière, P.J. 2004. ${ }^{40} \mathrm{Ar} /{ }^{39} \mathrm{Ar}$ dating in the Lochaber - Mulgrave area, northern mainland Nova Scotia: Implications for timing of regional metamorphism and sediment provenance in the Late Devonian - Early Carboniferous Horton Group. Canadian Journal of Earth Sciences, 41, pp. 987-996.

SCHILlER, E.A. 1961. Geological map of Guysborough, Map 27-1961. Geological Survey of Canada, Preliminary Series.

SмIтH, P.K. 1980. Geology of the Guysborough area, Guysborough County, Nova Scotia. In Mineral Resources Division, Report of Activities 1979. Edited by K.A. McMillan. Nova Scotia Department of Mines and Energy, Report 80-1, p. 109.

SмIтH, P.K. 1981. Horton Group stratigraphy in the Guysborough area, Nova Scotia. In Mineral Resources Division, Report of Activities 1980. Edited by K.A. Mills. Nova Scotia Department of Mines and Energy, Report 81-1, p. 37.

TÉNIÈRE, P. 2002. Stratigraphy, structure, and ${ }^{40} \mathrm{Ar} /{ }^{39} \mathrm{Ar}$ geochronology of the Horton Group in the Lochaber-Mulgrave area, Nova Scotia. Unpublished MSc thesis, Acadia University, Wolfville, Nova Scotia. 149 p.

TÉNière, P., Giles, P.S., \& NAYLOR, R.D. 2002. Stratigraphy of the Horton Group, Guysborough and Antigonish counties. In Minerals and Energy Branch, Report of Activities 2001. Edited by D.R. MacDonald. Nova Scotia Department of Natural Resources, Minerals and Energy Branch, Report 2002-1, pp. 129-139.

Thomas, D.B., Nance, R.D., \& Murphy, J.B. 2002. Deformation of the Macumber Formation, Antigonish Basin, Nova Scotia: implications for the Ainslie Detachment. Atlantic Geology, 38, pp. 135-144.

Utтing, J. 2001. Palynological examination of 47 outcrop samples and 5 subsurface samples from Nova Scotia submitted by P.S. Giles (NTS 11F/05, 11F/06, 11F/10, 11F/11, $11 \mathrm{~F} / 12,11 \mathrm{~F} / 14)$; unpublished paleotological report 1-JU2002, Natural Resources of Canada, Geological Survey of Canada (Calgary), $20 \mathrm{p}$.

Utting, J., \& Hamblin, A.P. 1991. Thermal maturity of the
Lower Carboniferous Horton Group, Nova Scotia. International Journal of Coal Geology, 19, pp. 439-456.

WAGNER, R.H. 1984. Megafloral zones of the Carboniferous. International Congress on Carboniferous Stratigraphy and Geology, 9(Vol 2), pp. 109-134.

WeBster, T.L. 1996. Remote sensing and geographic information system analysis of the St. Mary's Basin and surrounding areas, Central Nova Scotia. M.Sc. thesis, Acadia University, Wolfville, Nova Scotia. 165 p.

Webster, T.L., Murphy, J.B., \& Barr, S.M. 1998. Anatomy of a terrane boundary: an integrated structural, geographic information system, and remote sensing study of the late Paleozoic Avalon-Meguma terrane boundary, mainland Nova Scotia, Canada. Canadian Journal of Earth Sciences, 35, pp. 787-801.

White, C.E., \& BARR, S.M. 1998. Preliminary geological map of Guysborough, Richmond and Antigonish counties (parts of NTS sheets 11E/08, 11F/05, 11F/06, 11F/10, 11F/11, 11F/12 and 11F/15), Nova Scotia, Canada. Nova Scotia Department of Natural Resources, Minerals and Energy Branch, Open File Map 1998-001, scale 1:100 000.

White, C.E., \& BARR, S.M. 1999. Geology of the Guysborough-Mulgrave-L'Ardoise area: a progress report. In Minerals and Energy Branch, Report of Activities 1998. Edited by D.R. MacDonald and K.A. Mills. Nova Scotia Department of Natural Resources, Minerals and Energy Branch, Report 1999-1, pp. 105-117.

White, C.E., Barr, S.M, Ketchum, J.W.F., \& Ethier, M. 2001. Geology of the Cape Porcupine Complex (NTS 11F/11), Guysborough County, Nova Scotia. In Minerals and Energy Branch, Report of Activities 2000. Edited by D.R. MacDonald and K.A. Mills. Nova Scotia Department of Natural Resources, Minerals and Energy Branch, Report 2001-1, pp. 83-93.

Williams, G.L., Fyffe, L.R., Wardle, R.J., Colman-Sadd, S.P., \& BoeHner, R.C. 1985. Lexicon of Canadian Stratigraphy, volume VI, Atlantic Region.

Williams, P.F., Goodwin, L.B., \& LaFrance, B. 1995. Brittle faulting in the Canadian Appalachians and the interpretation of reflection seismic data. Journal of Structural Geology, 17, pp. 215-232. 